\title{
Anomalous somatic embryos in Acca sellowiana (O. Berg) Burret (Myrtaceae) ${ }^{1}$
}

\author{
ROSETE PESCADOR ${ }^{2,4}$, GILBERTO BARBANTE KERBAUY ${ }^{3}$, DANIELA VIVIANI ${ }^{2}$ \\ and JANE ELIZABETH KRAUS ${ }^{3}$
}

(received: August 02, 2007; accepted: February 21, 2008)

\begin{abstract}
Anomalous somatic embryos in Acca sellowiana (O. Berg) Burret (Myrtaceae). Somatic embryogenesis represents a valuable tool for the studies on the basic aspects of plant embryo development. Today this process is used as a potencial technique for large-scale plant micropropagation although, so far, it has been applied to only a small number of species. However, when somatic embryos are malformed they are considered economically useless. In Acca sellowiana (O. Berg) Burret, an important fruit-producing crop, large amounts of anomalous somatic embryos (76.3\%) were found just after 40 days of culture of explants in a 2,4-D containing medium. Among the anomalous forms found in the cotiledonary stage, $12.2 \%$ consisted of fused embryos, $40.4 \%$ displayed fused cotyledons, $13.0 \%$ presented supernumerary cotyledons, and $10.7 \%$ showed absence or poorly developed cotyledons, including those without the shoot apical meristem. Histological analyses indicated that the altered embryos were formed either directly from cotyledons, hypocotyl and radicle of the zygotic embryos used as explants, or indirectly from calli formed from these tissue parts. It is suggested that the formation of anomalous somatic embryos, as well as a low frequency of conversion into emblings reflect physiological and/or genetic disturbances triggered by the presence of 2,4-D in the medium. In vitro experimental alternative approaches are discussed in order to lessen the occurrence of malformed somatic embryos.
\end{abstract}

Key words - 2,4-D, feijoa, morphohistological analysis, somaclonal variation, somatic embryogenesis

RESUMO - (Embriões somáticos anômalos em Acca sellowiana (O. Berg) Burret (Myrtaceae)). A embriogênese somática representa uma ferramenta importante para estudos básicos do desenvolvimento das plantas. Atualmente este processo é utilizado como uma técnica com potencial para a micropropagação de plantas em grande escala, embora ainda com aplicação restrita a poucas espécies. Entretanto, quando são formados embriões somáticos anômalos a aplicação econômica é inviabilizada. Em Acca sellowiana (O. Berg) Burret, uma importante frutífera nativa, uma elevada quantidade de embriões somáticos com fenótipos alterados $(76,3 \%)$ foi encontrada já no $40^{\circ}$ dia de cultura na presença de 2,4-D. Entre esses, 12,2\% consistiam de embriões fundidos, $40,4 \%$ apresentavam cotilédones concrescidos, $13 \%$ possuíam mais de dois cotilédones e $10,7 \%$ não tinham cotilédones ou eles eram pouco desenvolvidos, incluindo os embriões sem meristema apical caulinar. As análises histológicas mostraram que os embriões malformados originavam-se tanto diretamente dos cotilédones, hipocótilo e radícula dos embriões zigóticos utilizados como explantes, como indiretamente de calos formados a partir dessas estruturas. Sugere-se que a formação de embriões somáticos anômalos, bem como a baixa taxa de seu desenvolvimento em plântulas ("emblings"), refletiria a ocorrência de distúrbios fisiológicos e/ou genéticos protagonizada pela presença de 2,4-D no meio de cultura. São indicadas algumas abordagens experimentais alternativas visando reduzir a ocorrência de embriões somáticos com malformações.

Palavras-chave - 2,4-D, análise morfo-histológica, embriogênese somática, feijoa, variação somaclonal

\section{Introduction}

Somatic embryogenesis has long been advocated as being an interesting system for studies of fundamental aspects of plant embryo development (Halperin 1995).

1. Part of a doctorate dissertation of the first author performed at the Universidade de São Paulo, Instituto de Biociências, Departamento de Botânica.

2. Universidade Regional de Blumenau, Departamento de Ciências Naturais, Caixa Postal 1507, 89010-971 Blumenau, SC, Brazil.

3. Universidade de São Paulo, Instituto de Biociências, Departamento de Botânica, Caixa Postal 11461, 05422-970 São Paulo, SP, Brazil.
It is also used as a technique to propagate plants in large scale (Gray \& Purohit 1991) but at the same time it is a prominent source of somaclonal variation (Larkin \& Scowcroft 1981) in a representative number of plants (Lazzeri et al. 1987, Fourré et al. 1997, Rodriguez \& Wetzstein 1998, Dedicová et al. 2000, Wilhelm et al. 2005). This certainly reduces the potential of somatic embryogenesis for phytotechnical purposes.

Acca sellowiana (O. Berg) Burret (Myrtaceae) (syn. Feijoa sellowiana O. Berg) is a native plant to the southern region of the Brazilian Plateau, and is also found in Uruguay and Argentina (Mattos 1990). Fundamental and applied researches on this species have been motivated 
by the fact that it produces edible fruits which are potentially of great economic interest. The somatic embryogenesis of this species was firstly reported by Cruz et al. (1990) and the structural and ultrastructural aspects of these processes were described by Canhoto \& Cruz (1996) and Canhoto et al. (1996). Until now, various studies have reported the formation of anomalous somatic embryos in this species (Cruz et al. 1990, Canhoto \& Cruz 1996, Canhoto et al. 1999, Cangahuala-Inocente et al. 2004). However, accurate information about the way in which the development of these malformed embryos takes place and the frequency in which they appear is still lacking.

The main goal of the present study is to describe the sequence of morphogenetic events involved in the development and formation of somatic embryos from Acca sellowiana explants and to trace back the ontogenetic origin of anomalous embryos by means of histological analyses. Furthermore, the possible role of 2,4dichlorophenoxyacetic acid (2,4-D), a growth-regulator which is known to affect both genetic and physiological levels of development, in the formation of anomalous embryos is discussed.

\section{Material and methods}

Mature zygotic embryos of Acca sellowiana were used as explants. Ripe fruits collected from a germoplasm plant collection of the Empresa de Pesquisa Agropecuária e Extensão Rural de Santa Catarina (EPAGRI), Estação Experimental de São Joaquim, SC, BRAZIL, were used to supply the seeds. The seeds were disinfected according to Guerra et al. (1997) before excising the zygotic embryos in an aseptic chamber. The explants were cultured on a basal medium containing full-strength macro- and microsalts (von Arnold \& Eriksson 1981), supplemented with vitamins (Morel \& Wetmore 1951), $4 \mathrm{mM}$ glutamine, $30 \mathrm{~g} \mathrm{~L}^{-1}$ sucrose, $7 \mathrm{~g} \mathrm{~L}^{-1}$ agar (Sigma $\left.{ }^{\circledR} \mathrm{A} 4550\right)$, and $20 \mu \mathrm{M}$ 2,4-D. The $\mathrm{pH}$ of the culture medium was adjusted to 5.8 before autoclaving at $120{ }^{\circ} \mathrm{C}, 151.95 \mathrm{kPa}$ for $20 \mathrm{~min}$. The cultures were maintained in the dark at $25 \pm 1{ }^{\circ} \mathrm{C}$ for 70 days. Two explants were inoculated in each test tube $(25 \times 150 \mathrm{~mm})$ containing $10 \mathrm{~mL}$ of medium. A total of 200 cultures were analyzed.

For structural studies, samples were collected every three days during the first 40 days, and then every ten days until the $70^{\text {th }}$ day of culture. In order to determine the amount of normal and anomalous embryos, 100 test tubes at the $40^{\text {th }}$ day of incubation were used, and 600 embryos randomly collected were analyzed under a stereomicroscope.

For histological analyses, samples were fixed in Karnovsky's solution (Karnovsky 1965), modified by using $1 \%$ glutaraldehyde in $0.1 \mathrm{M}$ phosphate buffer ( $\mathrm{pH} 7.2), 4 \%$ formaldehyde, and 0.2 M phosphate buffer ( $\mathrm{pH} 7.2$ ), 5:3:2 $(\mathrm{v} / \mathrm{v})$, for 4 hours at room temperature. Fixed material was dehydrated in a series of graded ethanol (50-95\%) and then embedded in historesin $\left(\right.$ Leica $\left.^{\circledR}\right)$. Longitudinal and transverse sections (5-7 $\mu \mathrm{m}$ thick) were obtained with a rotary microtome, mounted on glass slides and stained with $0.05 \%$ toluidine blue $\mathrm{O}$ (Color Index 52040) in $0.1 \mathrm{M}$ phosphate buffer ( $\mathrm{pH}$ 6.8) (O’Brien et al. 1965) for five minutes.

Some embryos were analyzed under a scanning electron microscopy (SEM). After fixation, the samples were dehydrated in a graded-ethanol series (50-100\%), critical-point dried with $\mathrm{CO}_{2}$, and coated with gold-palladium (Silveira 1989).

\section{Results}

Phenotype of embryos - The morphological features of several developmental stages of somatic embryos are shown in figures 1-7: globular (figure 1, arrow), cordiform (figures 1, asterisk and 2), torpedo (figure 3), and cotyledonary (figure 4), which were initially observed at the $21^{\text {st }}, 24^{\text {th }}, 27^{\text {th }}$ and $40^{\text {th }}$ day of incubation, respectively. On the $40^{\text {th }}$ day of culture many anomalous somatic embryos (figure 5) were detected such as fused ones, some lacking or with poorly developed cotyledons, others with supernumerary cotyledons, and also embryos with fused cotyledons (cupuliform cotyledons). Figure 6 shows anomalous somatic embryos with no cotyledons and without the shoot apical meristem or having poorly developed cotyledons after 70 days of culture. Figure 7 depicts a normal somatic embryo at the $70^{\text {th }}$ day of culture.

The development of embryos occurred in an asynchronous manner in a way that at any given time embryos in different stages of development were present (figure 4).

Frequency of somatic embryos - Table 1 shows the percentage of normal (23.7\%) and anomalous (76.3\%) somatic embryos in the cotyledonary stage $(n=600)$. Among the anomalous forms, $12.2 \%$ consisted of fused embryos, $40.4 \%$ displayed fused cotyledons, $13.0 \%$ presented supernumerary cotyledons, and $10.7 \%$ showed absence or poorly developed cotyledons, including those without the shoot apical meristem.

The frequency of somatic embryo conversion into emblings (plantlets) was low, approximately $10 \%$ after 70 days of culture.

Histological analysis of anomalous embryos - After six days in culture, the mature zygotic embryos of Acca sellowiana used as explants were still curved but slightly swollen. On the $9^{\text {th }}$ day of culture, part of the cotyledons, as well as the hypocotyl-root axis were slightly more swollen (figure 8) as a result of prominent cell elongation and a few localized cell division processes. In the adaxial 

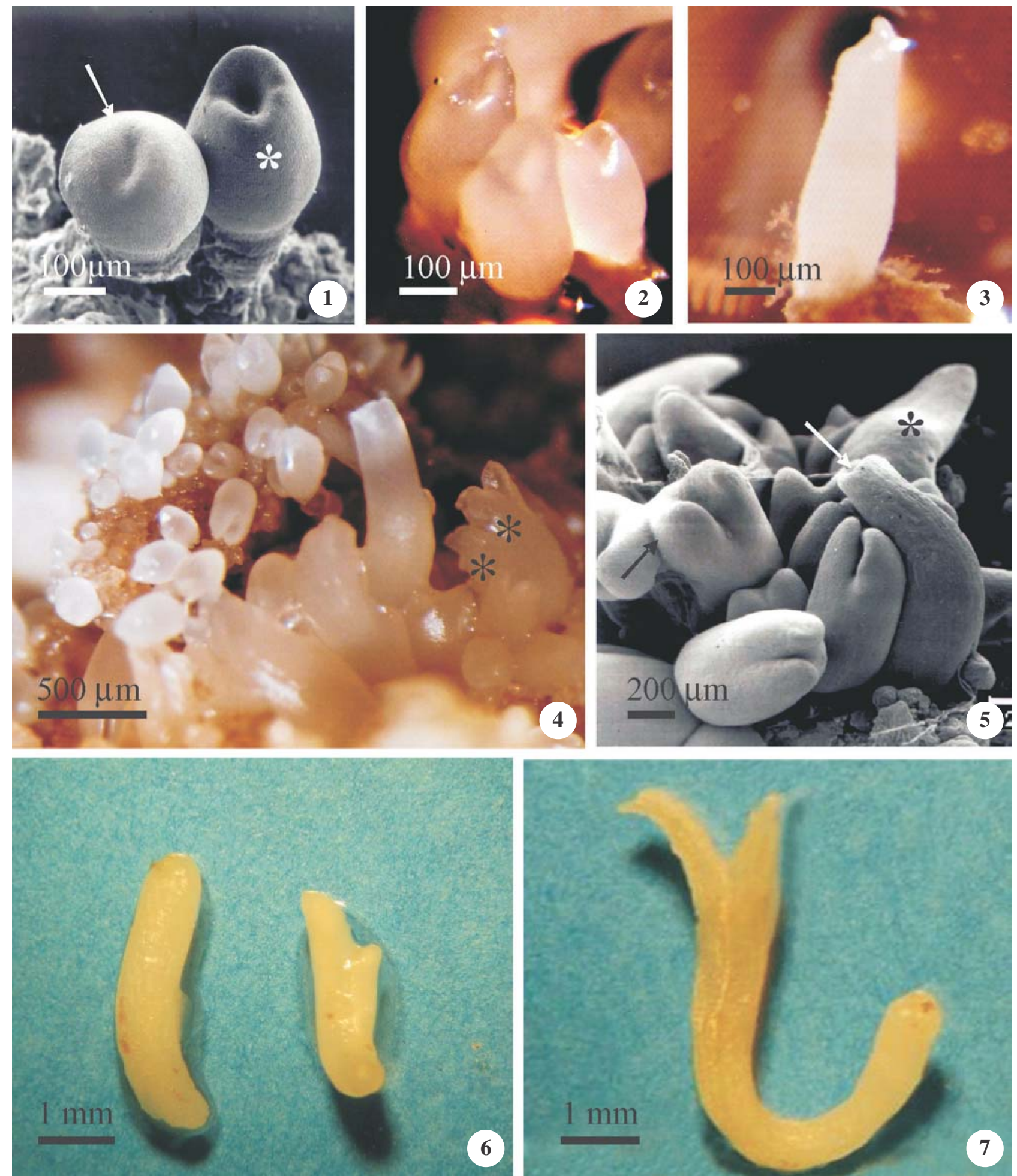

Figures 1-7. Somatic embryos of Acca sellowiana: morphological aspects. 1. 21 days in culture: embryos at the globular (white arrow) and cordiform (white asterisk) stages (SEM). 2. 24 days in culture: embryos at cordiform stage. 3. 27 days in culture: embryos at the torpedo stage. 4-5. 40 days in culture. 4. Embryos at the cotyledonary stage (black asterisks). 5. Embryos in different phases of development. Note anomalous somatic embryos: fused ones (black arrow), with fused cotyledons (white arrow) and without cotyledons (black asterisk). 6-7. 70 days in culture. 6. Anomalous somatic embryos: without cotyledons and shoot apical meristem (left) and with poorly developed cotyledons (right). 7. Normal somatic embryo. 
Table 1. Percentage of normal and anomalous embryos (fused embryos, fused cotyledons, supranumerary cotyledons and absence or poorly developed cotyledons*) of Acca sellowiana in the cotyledonary stage, at the $40^{\text {th }}$ day of culture $(n=600)$.

\begin{tabular}{|c|c|c|c|c|}
\hline $\begin{array}{c}\text { (\%) Normal embryos } \\
23.7\end{array}$ & & $(\%) \mathrm{A}$ & embryos & \\
\hline $\begin{array}{c}\text { Two } \\
\text { cotyledons }\end{array}$ & $\begin{array}{c}\text { Fused } \\
\text { embryos }\end{array}$ & $\begin{array}{c}\text { Fused } \\
\text { cotyledons }\end{array}$ & $\begin{array}{l}\text { Supranumerary } \\
\text { cotyledons }\end{array}$ & $\begin{array}{c}\text { Absence or poorly } \\
\text { developed cotyledons* }\end{array}$ \\
\hline 23.7 & 12.2 & 40.4 & 13.0 & 10.7 \\
\hline
\end{tabular}

* This category includes embryos without the shoot apical meristem.

surface of the explant cotyledon, the protoderm cells and cells from the first layers of the ground meristem were in the process of intense division (figure 9). Periclinal, anticlinal and oblique divisions of the cotyledonary protoderm occurred after 12 days of culture (figures 10 , 11 and 12, respectively). In some regions of the hypocotyl and radicle, proliferating cells were also observed. On the $21^{\text {st }}$ day several fused proembryos (figure 13), and proembryos like clusters of loosen cells (figure 14) were observed in the cotyledon.

In the 24-day-old cultures, proembryos were also formed in the hypocotyl (figure 15) and radicle (figure 16) of the explants. In parallel, calli were formed on part of cotyledon (figure 17), radicle (figure 18) and hypocotyl. The presence of somatic embryos developing from these calli was confirmed at the $30^{\text {th }}$ day of culture (figures 19-21).

Anomalous cotyledonary embryos were observed just after the $40^{\text {th }}$ day of incubation. Embryos with poorly developed cotyledons (figure 22), fused cotyledons (figure 23), and with elongated hypocotyl-root axis and without cotyledons (figure 24) occurred after 70 days of culture. In the latter kind of embryo, the shoot is deprived of apical meristem (figure 25), while the root apex is malformed (figure 26). For reasons of comparison, the shoot apical meristem of a normal embryo is also shown (figure 27).

\section{Discussion}

The present results corroborate existing data on both the high tendency for somatic embryo formation in Acca sellowiana as well as the high frequency of anomalous somatic occurrence in some explants of this species (Cruz et al. 1990, Canhoto et al. 1999). According to Canhoto et al. (1999), the most common abnormalities encountered are embryo fusion, the presence of more than two cotyledons, or cotyledonary fusion in a cup-like structure. In this paper the structural features of these anomalous embryos are described, including those which are characterized by the simultaneous absence of the shoot apical meristem and cotyledons, as mentioned by Cruz et al. (1990).

The histological analyses show that the somatic embryos of Acca sellowiana can be formed directly or indirectly from cotyledon, hypocotyls and radicle of the explant. The embryos were formed from: a) a single protoderm cell, with the first division occurring in periclinal, anticlinal or oblique plan; b) a cluster of protoderm cells; c) a cluster of ground meristematic cells near the protoderm; d) callus.

The occurrence of different planes of cell division in the determinated somatic embryonic cell of Acca sellowiana, which was formerly observed by Canhoto \& Cruz (1996), seems to reflect cell polarity disturbance. It could well be that this fact is involved in the proximate mechanism of anomalous embryo formation. In fact, according to Mayer et al. (1991) the gnom mutant of arabidopsis, characterized by a variable degree of inclined cell division planes, presented marked zygote phenotypical alterations. Arabidopsis thaliana (L.) Heynh. mutant plants for normal organization of shoot apical meristems as the shootmeristemless (stm), wuschell (wus) and gurke $(g k)$ present profound phenotypical changes (Torrez Ruiz et al. 1996, Clark 1997). Two other functionally redundant genes CUP-SHAPED COTYLEDON 1 (CUC1) and 2 (CUC2), are also necessary for the separation of the cotyledon primordia and for the formation of a functional shoot apical meristem in arabidopsis (Aida et al. 1999). Embryos with fused cotyledons and absence of cotyledons lacking shoot apical meristem are similar to what was found in some of the somatic embryos of Acca sellowiana.

Several other factors may underlie the remarkable structural changes detected during somatic embryogenesis in Acca sellowiana. Amongst them, it must be firstly highligthed the obligatory callus stage for the indirect route of somatic embryogenesis. It is generally accepted that callus has conspicuous mixoploidy as well as the 

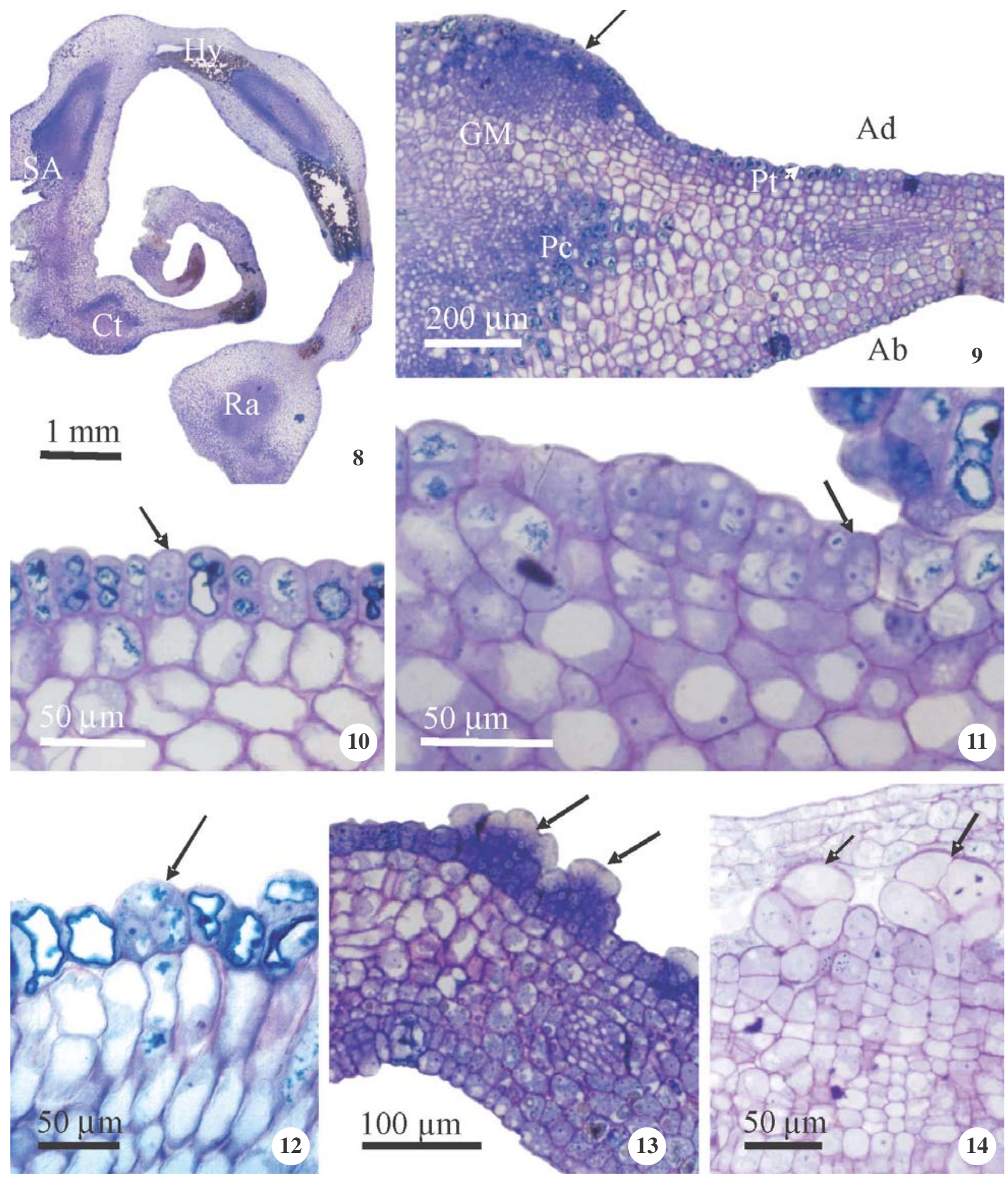

Figures 8-14. Somatic embryogenesis in Acca sellowiana: histological aspects. Longitudinal section (8). Transverse sections (9-14). 8-9. 9 days in culture. 8. Explant (zygotic embryo) showing swollen portions of the cotyledons and hypocotyl-root axis. 9. Swollen portion of the cotyledon explant: the arrow indicates regions of the proliferated tissues. 10-12. 12 days in culture: protoderm cells of the explant cotyledon. The arrow indicates periclinal (10), anticlinal (11) and oblique (12) divisions. 13-14. 21 days in culture. 13. Note fused proembryos (arrows) in the explant cotyledon. 14. Anomalous proembryos (arrows) developed in the cotyledon tissues of the explant. ( $\mathrm{Ab}=$ Abaxial surface; $\mathrm{Ad}=$ Adaxial surface; $\mathrm{Ct}=\mathrm{Cotyledon}$; $\mathrm{GM}=$ Ground Meristem; Hy = Hypocotyl; Pc = Procambium; Pt = Protoderm; Ra = Radicle; SA = Shoot Apex $)$. 

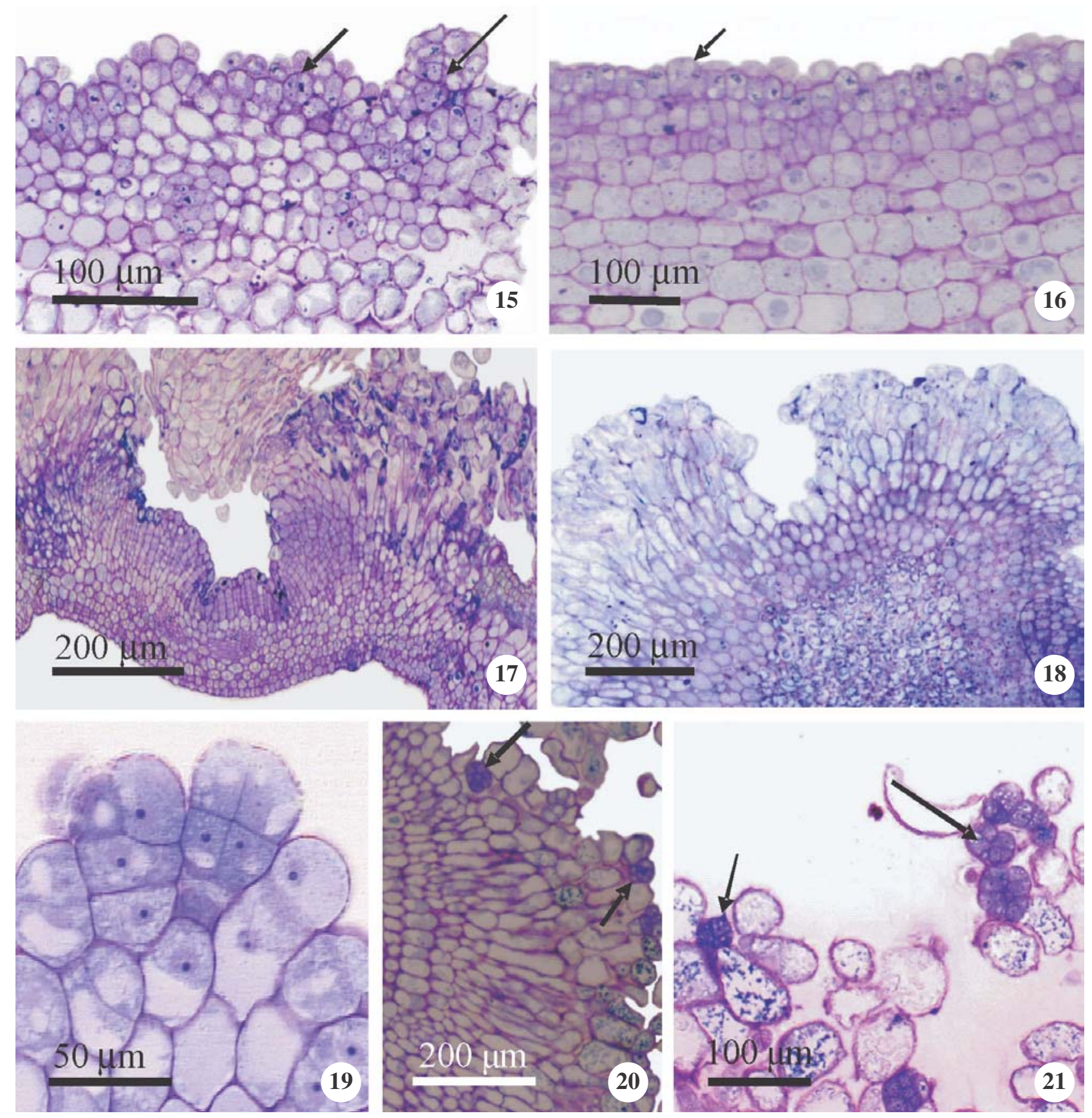

Figures 15-21. Somatic embryogenesis in Acca sellowiana: histological aspects. Longitudinal sections $(15,16,18,20,21)$. Transverse sections (17,19). 15-18. 24 days in culture: proembryos (arrows) developed in the hypocotyl (15) and radicle (16) of the explant; calli of the cotyledonary (17) and radicle (18) explant. 19-21. 30 days in culture: embryos (arrows) formed in the cotyledon (19), and in callus of the radicle (20). 21. Detail of the radicle embryos.

callus is originated from different explant tissues functioning both as a source of genetic alteration (D'Amato 1978). A relationship between Acca sellowiana anomalous somatic embryos formation and its multicellular origin (callus) was suggested some years ago by Canhoto \& Cruz (1996).
According to Cruz et al. (1990) the ease by which somatic embryogenesis is induced in Acca sellowiana would largely result from the relatively high level of 2,4D present in the culture medium. Fehér et al. (2003) advocated that this plant growth-regulator would generate the necessary triggering stress to enhance 

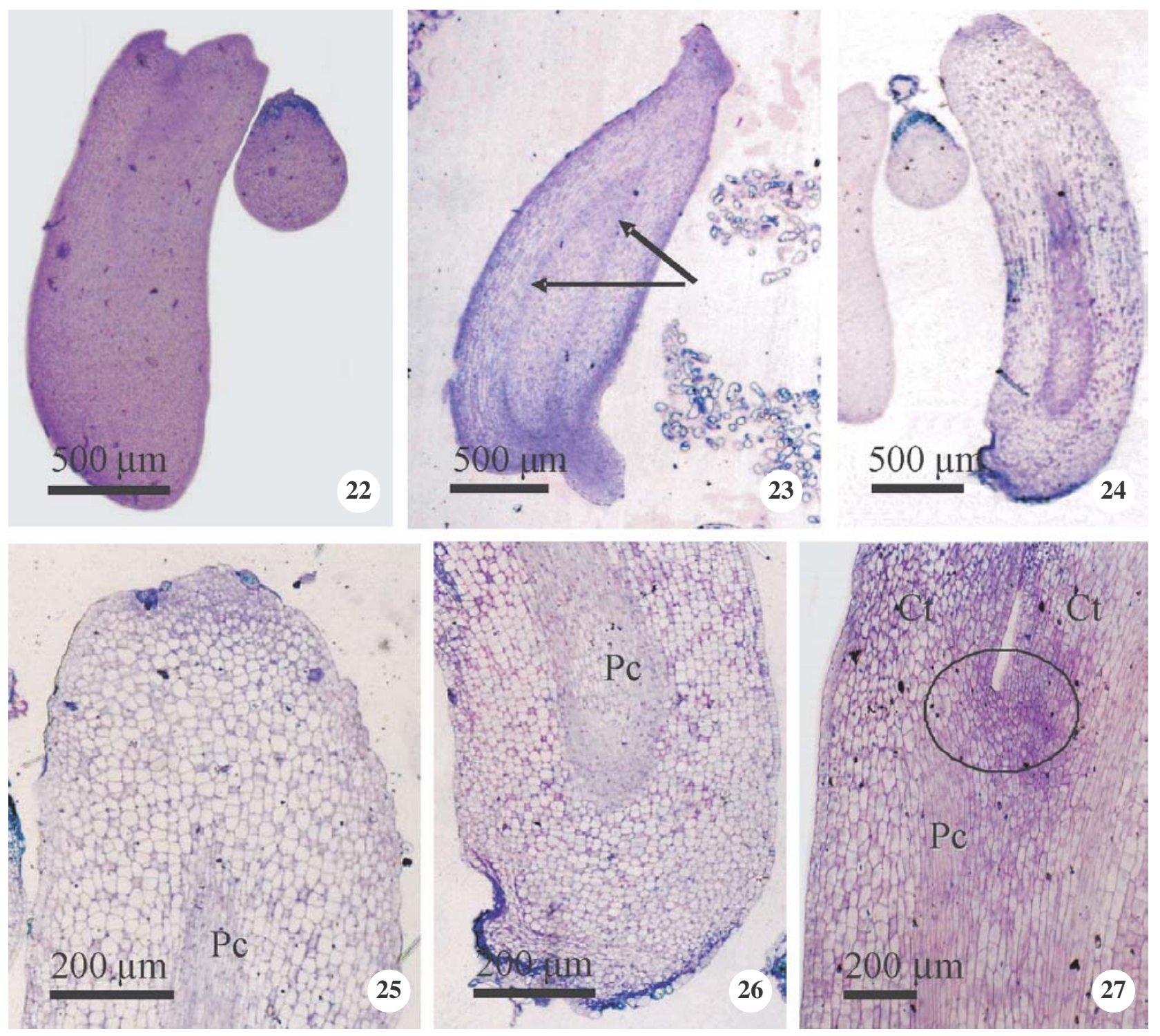

Figures 22-27. Somatic embryogenesis in Acca sellowiana: histological aspects. Longitudinal sections. 22-27. 70 days in culture. 22. Anomalous embryo with poorly developed cotyledons. 23. Embryo with fused cotyledons (cupuliform). Note the procambium (arrows). 24. Anomalous embryo without cotyledons. 25. Detail of shoot apex without the apical meristem (bind embryo). 26. Part of the hypocotyl-root axis showing a deformed radicle apex. 27. Shoot apex of normal embryo. $(\mathrm{Ct}=$ Cotyledon; $\mathrm{Pc}=$ Procambium $)$.

somatic embryogenic competence. It has also been postulated that the embryogenic effect of 2,4-D would derive from its methylating action on the nuclear DNA (De Klerk et al. 1997). In fact, large amounts of 2,4-D increased DNA methylation levels in carrot cultures (Kaeppler et al. 2000). Also in carrot cells, 2,4-D stimulated in particular the amount of endogenous IAA, which in turn, according to Michalczuk et al. (1992), would induce somatic embryogenic competence. According to postulated by Sharma et al. (2007), DNA methylation would be an indispensable process for initiating somatic embryogenesis but one that, at times, has the undesirable consequence of inducing also somaclonal variation, which can persist in regenerated plants and be partly transmitted to their progeny (Smulders et al. 1995).

The occurrence of anomalous somatic embryos has frequently been pointed out for plant species which were cultivated on 2,4-D containing media (Lazzeri et al. 1987, Rodriguez \& Wetzstein 1998, Dedicová et al. 2000). Thus, it is plausible to suggest that the anomalous embryos of Acca sellowiana resulted to a large extend 
from deleterious effects of 2,4-D on the normal genetic and/or physiological processes.

Apparently, the first evidence of the effect of phenolic acetic acids in malformed plantlets formation was presented by Haccius (1955) who worked with zygotic embryos of Eranthis hyemalis Salisb. A dose response effect of 2,4-D on the percentage of embryo abnormality was observed by the author. Haccius work preceded the classic work of Steward et al. (1958) on carrot somatic embryos induction without the use of 2,4-D. Halperin \& Wetherell (1969) observed the abnormal development of apical meristems and further inhibited growth on carrot embryos when they were treated with relative high concentrations of 2,4-D.

Deleterious effects of $2,4-\mathrm{D}$ on the in vitro chromosomal feature such as endoreduplication, aneuploidy and polyploidy have been observed in several species (Nagl \& Rücker 1972, Chand \& Roy 1980). Recently Araújo et al. (2005) comparing the frequencies of transposable elements in sugarcane leaf, flower, apical meristem and embryogenic calli grown on 2,4-D enriched medium, observed that the culture condition strongly induced the expression of different transposable elements.

Disturbance in the polar transport of auxin in 2,4-D somatic embryo was pointed out by Liu \& Chua (1993), and Rodriguez \& Wetzstein (1994). In fact, 2,4-D can change the conformation of the PIN protein, negatively interfering with the efflux of IAA, and altering the normal establishment of the apical-basal somatic embryos axis (Friml et al. 2003). At least two arabidopsis mutants for auxin signaling ( $b d l$ and $m p$ ) were shown to block the formation of the central and basal regions of the embryo and these defects could be traced back to the two-cell stage where the apical cell divides horizontally rather than vertically (Berleth \& Jürgens 1993, Hamann et al. 1999). Comparative hormonal studies performed with corresponding zygotic and somatic 2,4-D-formed embryo stages of Acca sellowiana showed profound differences in their ABA, IAA and cytokinins endogenous levels (Pescador 2004).

It is also important to mention that a low rate of conversion of somatic embryos into emblings is frequently obtained in Acca sellowiana. Cangahuala-Inocente et al. (2007) indicated $22.5 \%$ and $19 \%$ of conversion of somatic embryos into emblings after 30 and 45 days of culture, respectively. Our results point to $10 \%$ of conversion after 70 days of culture, and the low rate of emblings obtained was associated with the high percentage of anomalous somatic embryos formed. Cruz et al. (1990) also proposed that the large number of abnormal somatic embryos reduces their post-embryonic development.

The view that emerges from the present results and those reported in the literature is that the formation of anomalous somatic embryos, as well as its low frequency of conversion into emblings in Acca sellowiana, is probably due to the effect of 2,4-D in the medium which seems to disrupt normal genetic and physiological processes.

For several species, the practically obligatory use of 2,4-D coupled with the use of mature polysomatic explants instead of meristematic ones, and callus stage for somatic embryogenesis induction seem to be among the most prominent candidates in triggering anomalous somatic embryo formation. Therefore, it seems highly necessary to exploit alternative strategies to minimize or eliminate the deleterious effects (arising from the application) of the conventional somatic embryogenesis protocols so far used for plant micropropagation. One of these strategies would be to highlight the necessary determination of a minimal pulse with 2,4-D (initial stress factor) as proposed by Canhoto et al. (1999) instead of long-term culture, or even substitute 2,4-D by another weaker growth regulator. In parallel, efforts should be directed toward a partial or even total substitution of 2,4-D by a non-hormonal or even abiotic stress factor that could trigger the necessary competence for morphogenetic responses (Potters et al. 2007). For example, according to Pasternak et al. (2002), the stimulatory effect of 2,4-D on somatic embryo formation could be partially replaced by iron stress applied at a sub-lethal concentration.

Acknowledgements - G.B. Kerbauy thanks the Conselho Nacional de Desenvolvimento Científico e Tecnológico (CNPq) for the research grant. The authors thank Dr Jorge Ernesto A. Mariath of the Universidade Federal do Rio Grande do Sul (UFRGS) for his valuable contributions.

\section{References}

AIDA, M., ISHIDA, T. \& TASAKA, M. 1999. Shoot apical meristem and cotyledon formation during Arabidopsis embryogenesis: interaction among the CUP-SHAPED COTYLEDON and SHOOT MERISTEMLESS genes. Development 126:1563-1570.

ARAÚJO, P.G., ROSSI, M., JESUS, E.M., SACCAROJUNIOR, N.L., KAJIHARA, D., MASSA, R., FELIX, J.M., DRUMMOND, R.D., FALCO, M.C., CHABREGAS, S.M., ULIAN, E.C., MENOSSI, M. \& VAN SLUYS, M-A. 2005. Transcriptonally active transposable elements in recent hybrid sugarcane. The Plant Journal 44:707-717. 
BERLETH, T. \& JÜRGENS, G. 1993. The role of the monopteros gene in the organizing the basal body region of the Arabidopsis embryo. Development 118:575-587.

CANGAHUALA-INOCENTE, G.C., STEINER, N., SANTOS, M. \& GUERRA, M.P. 2004. Morphohistological analysis and histochemistry of Feijoa sellowiana somatic embryogenesis. Protoplasma 224:33-40.

CANGAHUALA-INOCENTE, G.C., DAL VESCO, L.L., STEINMACHER, D., TORRES, A.C. \& GUERRA, M.P. 2007. Improvements in somatic embryogenesis protocol in Feijoa (Acca sellowiana (Berg) Burret): induction, conversion and synthetic seeds. Scientia Horticulturae 111:228-234.

CANHOTO, J.M. \& CRUZ, G.S. 1996. Histodifferentiation of somatic embryos in cotyledons of pineapple guava (Feijoa sellowiana Berg). Protoplasma 191:34-45.

CANHOTO, J.M., MESQUITA, J.F. \& CRUZ, G.S. 1996. Ultrastructural changes in cotyledons of pineapple guava (Myrtaceae) during somatic embryogenesis. Annals of Botany 78:513-521.

CANHOTO, J.M., LOPES, M.L. \& CRUZ, G.S. 1999. Somatic embryogenesis in myrtaceous plants. In Somatic embryogenesis in woody plants (S.M. Jain, P.K. Gupta \& R.J. Newton, eds.). Kluwer Academic Publishers, Dordrecht, v.4, p.294-340.

CHAND, S. \& ROY, S.C. 1980. Effect of different auxins on chromosome behaviour of leaf callus tissues of Nigela sativa. Caryologia 33:387-392.

CLARK, S.E. 1997. Organ formation at the vegetative shoot meristem. Plant Cell 9:1087-1076.

CRUZ, G.S., CANHOTO, J.M. \& ABREU, M.A.V. 1990. Somatic embryogenesis and plant regeneration from zygotic embryos of Feijoa sellowiana Berg. Plant Science 66:263-270.

D'AMATO, F. 1978. Chromosome number variation in cultured cell and regenerated plants. In Frontiers of plant tissue culture (T.A. Thorpe, ed.). University of Calgary Offset Print Services, Calgary, p.287-295.

DE KLERK, G.J., ARNHOLDT-SCHMITT, B., LIEBEREI, R. \& NEUMANN, K.H. 1997. Regeneration of roots, shoots and embryos: physiological, biochemical and molecular aspects. Biologia Plantarum 39:53-66.

DEDICOVÁ, B., HRICOVÁ, A., ŠAMAJ, J., OBERT, B., BOBÁK, M. \& PRET'OVÁ, A. 2000. Shoots and embryo-like structures regenerated from cultured flax (Linum usitatissimum L.) hypocotyl segments. Journal of Plant Physiology 157:327-334.

FEHÉR, A., PASTERNAK, T.P. \& DUDITS, D. 2003. Transition of somatic plant cells to an embryogenic state. Plant, Cell, Tissue and Organ Culture 74:201-228.

FOURRÉ, J.L., BERGER, P., NIQUET, L. \& ANDRÉ, P. 1997. Somatic embryogenesis and somaclonal variation in Norway spruce: morphogenetic, cytogenetic and molecular approach. Theoretical and Applied Genetics 94:159-169.
FRIML, J., VIETEN, A., SAUER, M., WEIJERS, D., SCHWARZ, H., HAMANN, T., OFFRINGA, R. \& JÜRGENS, G. 2003. Efflux-dependent auxin gradients establish the apical-basal axis of Arabidopsis. Nature 426:147-153.

GRAY, D.J. \& PUROHIT, A. 1991. Somatic embryogenesis to seed and development of synthetic seed technology. Critical Reviews in Plant Sciences 10:33-61.

GUERRA, M.P., PESCADOR, R., DAL VESCO, L.L., NODARI, R.O. \& DUCROQUET, J.P.H.J. 1997. In vitro morphogenesis in Feijoa sellowiana: somatic embryogenesis and plant regeneration. Acta Horticulturae 452:27-36.

HACCIUS, B. 1955. Experimentally induced twinning in plants. Nature 176:355-356.

HALPERIN, W. 1995. In vitro embryogenesis: some historical issues and unresolved problems. In In Vitro Embryogenesis in Plants (T.A. Thorpe, ed.). Kluwer Academic Publishers, Dordrecht, p.1-16.

HALPERIN, W. \& WETHERELL, D.F. 1969. Adventive embryony in tissue cultures of the wild carrot, Daucus carota. American Journal of Botany 51:274-283.

HAMANN, T., MAYER, U. \& JURGENS, G. 1999. The auxin-insensitive bodenlos mutation affects primary root formation and apical-basal patterning in the Arabidopsis embryo. Development 126:1387-1395.

KAEPPLER, S.M., KAEPPLER, H-F. \& RHEE, Y. 2000. Epigenetic aspects of somaclonal variation in plants. Plant Molecular Biology 43:179-188.

KARNOVSKY, M.J. 1965. A formaldehyde-glutaraldehyde fixative of high osmolality for use in electron microscopy. Journal of Cell Biology 27:137-138.

LARKIN, P.J. \& SCOWCROFT, W.R. 1981. Somaclonal variation - a novel source of variability from cell cultures for plant improvement. Theoretical and Applied Genetics 60:167-214.

LAZZERI, P.A., HILDEBRAND, D.F. \& COLLINS, G.B. 1987. Soybean somatic embryogenesis: effects of hormones and culture manipulations. Plant, Cell, Tissue and Organ Culture 10:197-208.

LIU, Z.X. \& CHUA, N. 1993. Auxin polar transport is essential for the establishment of bilateral symmetry during early plant embryogenesis. Plant Cell 5:621-630.

MATTOS, J.R. 1990. Goiabeira serrana - Fruteiras nativas do Brasil. 2 ${ }^{\underline{a}}$ ed. Editora Gráfica Ceue, Porto Alegre.

MAYER, U., TORRES RUIZ, R.A., BERLETH, T., MISÉRA, S. \& JÜRGENS, G. 1991. Mutations affecting body organization in the Arabidopsis embryo. Nature 353: 402-407.

MICHALCZUK, L., RIBNICKY, D.M., COOKE, T.J. \& COHEN, J.D. 1992. Regulation of indole-3-acetic acid biosynthetic pathways in carrot cell cultures. Plant Physiology 100:1346-1353.

MOREL, G.M. \& WETMORE, R.H. 1951. Tissue culture of monocotyledons. American Journal of Botany 38:138-140. 
NAGL, W. \& RÜCKER, W. 1972. Beziehungen Zwischen Morphogenese und Nuklearem DNS-gehalt bei Aseptischen Kulturen von Cymbidium nach Wuchsstoff-behandlung. Zeitschrift fur Pflanzenphysiologie 67:120-134.

O'BRIEN, T.P., FEDER, N. \& MCCULLY, M.E. 1965. Polychromatic staining of plant cell walls by toluidine blue O. Protoplasma 59:368-373.

PASTERNAK, T., PRINSEN, E., AYAYDIN, F., MISKOLCZI, P., POTTERS, G., ASARD, H., VAN ONCKELEN, H. A., DUDITS, D. \& FEHÉR, A. 2002. The role of auxin, $\mathrm{pH}$, and stress in the activation of embryogenic cell protoplast-derived cells of alfalfa. Plant Physiology 129: 1807-1819.

PESCADOR, R. 2004. Aspectos fisiológicos e estruturais das embriogêneses zigótica e somática de Feijoa sellowiana Berg., Myrtaceae. Tese de doutorado, Universidade de São Paulo, São Paulo.

POTTERS, G., PASTERNAK, T.P., GUISEZ, I., PALME, K.J. \& JANSEN, M.A.K. 2007. Stress induced morphogenic responses: growing out or trouble? Trends in Plant Science 12:98-105

RODRIGUEZ, A.P.M. \& WETZSTEIN, H.Y. 1994. The effect of auxin type and concentration on pecan (Carya illinoinensis) somatic embryo morphology and subsequent conversion into plants. Plant Cell Reports 13:607-611.

RODRIGUEZ, A.P.M. \& WETZSTEIN, H.Y. 1998. A morphological and histological comparison of the initiation and development of pecan (Carya illinoinensis) somatic embryonic cultures induced with naphthalenic acetic acid or 2,4-dichlorophenoxyacetic acid. Protoplasma 204:71-83.
SHARMA, S.K, BRYAN, J.B, WINFIELD, M.O. \& MILLAM, S. 2007. Stability of potato (Solanum tuberosum L.) plants regenerated via somatic embryos, axillary bud proliferated shoots, microtubers and true potato seeds: a comparative phenotypic, cytogenetic and molecular assesment. Planta 226:1449-1458.

SILVEIRA, M. 1989. Preparo de amostras biológicas para microscopia eletrônica de varedura. In Manual sobre técnicas básicas em microscopia eletrônica (W. Souza, ed.). Sociedade Brasileira de Microscopia Eletrônica, Rio de Janeiro, p.71-90.

SMULDERS, M.J.M, RUS-KORTEKAAS, W. \& VOSMAN, B. 1995. Tissue culture-induce DNA methylation polymorphism in repetitive DNA of tomato calli and regenerated plants. Theoretical Applied Genetic 91: 1257-1264.

STEWARD, F.C., MAPES, M.O. \& MEARS, K. 1958. Growth and organized development of cultured cells. II. Organization in cultures grown from freely suspended cells. American Journal of Botany 45:704-708.

TORREZ RUIZ, R.A., LOHNER, A. \& JÜRGENS, G. 1996. The GURKE gene is required for normal organization of the apical region in the Arabidopsis embryo. Plant Journal 10:1005-1016.

VON ARNOLD, S. \& ERIKSSON, T. 1981. In vitro studies of adventitious shoot formation in Pinus cordata. Canadian Journal of Botany 59:870-874.

WILHELM, E., HRISTOFOROGLU, K., FLUCH, S. \& BURG, K. 2005. Detection of microsatellite instability during somatic embryogenesis of oak (Quercus robur L.). Plant Cell Reports 23:790-795. 